\title{
RESEARCH
}

Open Access

\section{Efficacy of biopesticides against the whitefly, Bemisia tabaci (Gennadius) (Hemiptera: Aleyrodidae), on parthenocarpic cucumber grown under protected environment in India}

\author{
Dilip Shriram Ghongade ${ }^{1^{*}}$ and K. S. Sangha ${ }^{2}$
}

\begin{abstract}
Background: The whitefly, Bemisia tabaci (Genn.) (Hemiptera: Aleyrodidae), is one of the most damaging pests of crops grown in open field and under protected conditions. Owing to the indiscriminate use of insecticides, whitefly has developed resistance against various insecticides belonging to different chemical groups. Use of microbial biopesticides (entomopathogenic fungi) can be an effective alternate to chemical insecticides.

Results: This study was planned for the evaluation of entomopathogenic fungi (EPF) formulations, namely, Beauveria bassiana Balsamo (Vuillemin), Lecanicillium lecanii (Zimmerman) Viegas and Metarhizium anisopliae (Metschnikoff) Sorokin and botanical pesticide, Neem Baan, for the management of different life stages of B. tabaci on parthenocarpic cucumber grown under protected conditions. The liquid formulations of Neem Baan at 10 and $15 \mathrm{ml} / \mathrm{l}$ were the most effective ( 90.7 to $93.3 \%$ in eggs, 93.3 to $97.1 \%$ in nymphs, and 92.4 to $94.2 \%$ reduction in whitefly adults after 3rd spray, respectively) as compared to EPF. Among the EPF, L. lecanii and B. bassiana at 10 and $15 \mathrm{ml} / \mathrm{l}$ (80.6 to $86.5 \%$ in eggs, 85.7 to $91.5 \%$ in nymphs, and 58.5 to $69.2 \%$ in whitefly adults after 3rd spray, respectively) were found to be more effective than $M$. anisopliae at 10 and $15 \mathrm{ml} / \mathrm{l}(78.4$ to $82.8 \%$ in eggs, 82.5 to $85.9 \%$ in nymphs, and 57.7 to $62.8 \%$ in whitefly adults after third spray, respectively) in reducing different life stages of B. tabaci on cucumber. Significantly high yield of cucumber fruits was obtained from the plot where Neem Baan at 10 and $15 \mathrm{ml} / \mathrm{l}$ (2337.5 to $2420.8 \mathrm{~g} /$ plant) was used. Minimum fruit yield were recorded in untreated control plots. Conclusions: The integration of these biopesticides in the management schedule of the whitefly under protected conditions will enhance the quality and market value of parthenocarpic cucumbers.
\end{abstract}

Keywords: Bemisia tabaci, Entomopathogenic fungi, India, Parthenocarpic cucumber, Protected environment

\footnotetext{
* Correspondence: dilipghongade63@gmail.com

'Department of Entomology, Punjab Agricultural University, Ludhiana

141004, India

Full list of author information is available at the end of the article
}

\section{Springer Open}

(c) The Author(s). 2021 Open Access This article is licensed under a Creative Commons Attribution 4.0 International License, which permits use, sharing, adaptation, distribution and reproduction in any medium or format, as long as you give appropriate credit to the original author(s) and the source, provide a link to the Creative Commons licence, and indicate if changes were made. The images or other third party material in this article are included in the article's Creative Commons licence, unless indicated otherwise in a credit line to the material. If material is not included in the article's Creative Commons licence and your intended use is not permitted by statutory regulation or exceeds the permitted use, you will need to obtain permission directly from the copyright holder. To view a copy of this licence, visit http://creativecommons.org/licenses/by/4.0/. 


\section{Background}

The whitefly, Bemisia tabaci (Gennadius) (Hemiptera: Aleyrodidae), is a devastating pest of vegetables, ornamentals, and agricultural crops throughout the tropical and subtropical regions of the world (Oliveira et al. 2001). More than 900 plant species are known to be its hosts (GISD 2005). The suitable hosts that support the B. tabaci population include cotton, cabbage, tomato, eggplant, okra, cucumber, squash, melon, and many ornamentals (Li et al. 2011).

Cucumber, Cucumis sativus L., is an important cucurbitaceous vegetable cultivated under different environmental conditions, open fields, and greenhouses for local consumption and exportation. Polynet houses/net houses provide suitable microclimatic conditions for the growth and development of sucking pests. Warm humid conditions are preferred by the sap-sucking insects. The highest population levels force the farmers to use excessive usage of chemicals.

Parthenocarpic cucumbers are one of the important commercial crops grown under protected environment and are the money spinners for the farming community (Sood et al. 2018).

The whitefly, B. tabaci, is one of the most important pests infesting cucumber plants during its three growth stages, seedling, flowering, and fruiting. This pest inflicts damage in two ways: (a) it affects the plant vitality and vigor by sucking significant amount of phloem sap and (b) by interfering in the normal photosynthesis due to growth of sooty mold fungus on the honeydew excreted. This significantly affected the quality and marketability of the harvested products (Oliveira et al. 2001). Whitefly also acts as vectors of several economically important viral plant pathogens causing huge yield losses (van Regenmortel et al. 2000).

Favorable microclimate, availability of tender plant parts for a long period, and more number of generations under poly-house conditions make whitefly management more difficult. Also, all the life stages of whitefly colonize the abaxial surface of leaves, which makes it difficult to achieve effective coverage by insecticidal spraying, leading to frequent applications. Adverse effects like pesticide residues on crop produce (Van Lenteren 2000), killing of non-target organisms (Pilkington et al. 2010), and development of resistance to pesticides (Pappas et al. 2013) are associated with frequent and excessive use of insecticides. It sometimes resulted in the resurgence of the pests making their control more difficult, expensive, and environmentally devastating. Hence, emphasis is being part on insecticide-free control strategies or management of vegetable pests. A long-term irreversible effects of indiscriminate insecticides' usage have necessitated the increased usage reliance on biological control methods (Torrado-Leon et al. 2006).
Entomopathogenic fungi (EPF) have been identified as potential control agents against B. tabaci (Saito and Sugiyama 2005). Beauveria bassiana (Balsamo) Vuillemin, Lecanicillium lecanii (Zimmerman), Metarhizium anisopliae (Metsch.), and Paecilomyces fumosoroseus (Wize) are key tools for the management of various agricultural insect pests, including whiteflies, mealy bugs, aphids, thrips, psyllids, and weevils in outdoor and greenhouse crops (Torrado-Leon et al. 2006; Akmal et al. 2013). Efficacy of EPF against both eggs and nymphal instars of whitefly has been widely demonstrated (Saito and Sugiyama 2005; Park and Kim 2010; Norhelina et al. 2013).

Owing to the increasing threats of whitefly infestation on cucumber crop and the need for residue-free organic crop, this study was carried out to evaluate the efficacy of EPF formulations on different developmental stages of the whitefly, B. tabaci, on parthenocarpic cucumber grown under protected conditions.

\section{Methods}

A field experiment was conducted to evaluate the efficacy of different biopesticides against the whitefly, $B$. tabaci on parthenocarpic cucumber grown under net house (size, $15 \times 7 \mathrm{~m}=105 \mathrm{~m}^{2}$ ). The experiment was conducted in a double-door fated naturally ventilated poly-house structure made of galvanized iron pipes covered with ultraviolet stabilized 40 mesh size net and an arc shaped dome. The trial was laid out at the experimental farm of Department of Vegetable Science during August to December 2017 and 2018 for raising autumn season crops. Thirty-day-old seedlings $\mathrm{F}_{1}$ hybrid Punjab Kheera-1: Plant is vigorous, bearing 1-2 fruits per node. It is suitable for poly-net house only. Seedlings were transplanted during the last week of August in 2017 and 2018 seasons, keeping row to row and plant to plant distance of $60 \mathrm{~cm} \times 30 \mathrm{~cm}$, respectively. Seedlings were transplanted on $30-\mathrm{cm}$ raised beds. The crop was raised in insecticide free environment by following recommended cultural and management practices for the production of cucumber under naturally ventilated polyhouse (Anonymous 2018). Cucumber plants were trained on single shoots with the help of bamboos and nylon ropes. The extra shoots were pruned regularly to optimize the growth of plants.

\section{Collection and rearing of insects}

A stock culture of $B$. tabaci was maintained on young potted plants of cucumber under screen-house conditions to ensure availability of large number of whiteflies required for artificial infestation of cucumber plants. For this purpose, whitefly adults were initially collected from whitefly infested cucumber plants grown in poly-houses and the identity of species was ascertained prior to raising the cultures. The identified B. tabaci adults were 
Table 1 Biopesticides evaluated against Bemisia tabaci on cucumber under net house conditions

\begin{tabular}{|c|c|c|c|}
\hline Treatment & Concentrations (\% or ml/l) & Brand name & Formulator \\
\hline $\begin{array}{l}\text { Neem Baan (1\% W/W) } \\
\text { (Azadirachtin } 1000 \text { ppm) }\end{array}$ & $10 \mathrm{ml}$ and $15 \mathrm{ml} / \mathrm{l}$ & Nimbecidine & T. Stanes and Company Limited \\
\hline $\begin{array}{l}\text { Beauveria bassiana } 1.50 \% \\
{\left[1 \times 10^{9} \mathrm{CFU} / \mathrm{ml}\right]}\end{array}$ & $10 \mathrm{ml}$ and $15 \mathrm{ml} / \mathrm{l}$ & Bio-Power & T. Stanes and Company Limited \\
\hline $\begin{array}{l}\text { Lecanicillium lecanii 1.50\% } \\
{\left[1 \times 10^{9} \mathrm{CFU} / \mathrm{ml}\right]}\end{array}$ & $10 \mathrm{ml}$ and $15 \mathrm{ml} / \mathrm{l}$ & Bio-Catch & T. Stanes and Company Limited \\
\hline Metarhizium anisopliae $1.5 \%\left[1 \times 10^{8} \mathrm{CFU} / \mathrm{ml}\right]$ & $10 \mathrm{ml}$ and $15 \mathrm{ml} / \mathrm{l}$ & Bio-Magic & T. Stanes and Company Limited \\
\hline Malathion $50 \mathrm{EC}$ & $4 \mathrm{ml} / \mathrm{l}$ & Hilmala & Kalyani Industries Lmited \\
\hline Control (No spray) & - & - & \\
\hline
\end{tabular}

released in large numbers on potted plants of cucumber with the help of aspirator. Older and heavily infested plants were periodically replaced by fresh potted ones. It was practiced regularly throughout the study period.

\section{Testing of biopesticides}

Efficacy of different biopesticides including EPF and Neem formulations along with Malathion was evaluated for the management of $B$. tabaci on parthenocarpic cucumber grown under naturally ventilated polyhouse (Table 1).

\section{Experiment protocol}

The experiment was laid out in a randomized block design (RBD) with each concentration of biopesticide as one treatment and 3 replications/ treatment were kept. Apart from these biopesticide treatments (2 dosages), one chemical, Malathion 50 EC (one dosage), and untreated check (no spray) was also maintained for comparison.

There were 10 plants per plot in each biopesticide treatment, separated by distance of $50 \mathrm{~cm}$ between 2 plots to avoid chemical interference owing to drift to adjacent treatments. Large numbers of whitefly adults were released in the poly-house 35 days after transplanting (DAT) for early build-up of infestations. For foliar applications of the different biopesticides, a battery-operated knapsack sprayer fitted with hollow cone nozzle (40 PSI pressure) was used. The biopesticides were applied late in the afternoon hours.

\section{Data collection}

The observations were recorded on population build-up of whitefly in different biopesticide treatments. There were 3 foliar sprays for all treatments. The first was applied after 55 and 60 days of transplanting (in 2017 and 2018) and repeated at 11 days interval, respectively. Pretreatment and post-treatment observations were recorded on randomly selected 5 plants per plot. The pre-treatment observations (during 2017: 3.6 to 5.7 eggs/ leaf, 14.3 to 19.3 nymphs/leaf, and 5.9 to 7.1 adults/3 leaves; during 2018: 3.3 to 5.4 eggs/leaf, 14.9 to 18.0 nymphs/leaf, and 5.8 to 7.4 adults/3 leaves) were recorded $24 \mathrm{~h}$ before spray. The post treatment observations on whitefly eggs and nymphs were recorded from single leaf of the middle canopy of the plant. Adult populations were recorded from 3 leaves each on top, middle, and bottom canopy of the plant. The populations were recorded from randomly selected 5 plants per plot at 10 days' interval after each spray.

The leaves with eggs and nymphs of whitefly were collected and brought to the laboratory. Their numbers were recorded per leaf under a stereo zoom binocular microscope. The observations recorded were analyzed statistically to workout relative efficacy of different biopesticide treatments. Percent reduction in the population of whiteflies (eggs, nymphs, and adults) over control was calculated, using Henderson and Tilton's formula (Henderson and Tilton's 1955).

$$
\text { Corrected Mortality } \%=\left(1-\frac{\mathrm{n} \text { in Co before treatment } * \mathrm{n} \text { in T after treatment }}{\mathrm{n} \text { in Co after treatment } * \mathrm{n} \text { in T before treatment }}\right) * 100
$$

where $n=$ whitefly population; $\mathrm{T}=$ treated; $\mathrm{Co}=$ control.

\section{Marketable fruit yield}

Fruits reaching marketable size (about $15 \mathrm{~cm}$ in length) were harvested at 5 days interval. Fresh fruit weight per plant at each picking in different treatments was recorded. The fruit weight obtained at each picking was summed up to obtain cumulative fruit yield per plant during the crop season.

\section{Recording of environmental parameters}

Environmental parameters viz. minimum and maximum temperature and relative humidity were recorded daily with the help of digital thermo-hygro meter placed inside the polyhouse at canopy height throughout the study period. 


\section{Statistical analysis}

The mean population of the whitefly eggs, nymphs, and adults ( $x \pm$ SE PROC) were subjected to analysis of variance (ANOVA), and mean values were compared by Duncan Multiple Range Test (DMRT) $(P=0.05)$, using SPSS program, version 23 (SPSS 2015), and treatment means were separated at $P=0.05$. The analysis of variance was done for the each year separately. Pooled analysis was also done by pooling of treatment PROC values across the sprays for the respective years for all developmental stages of whitefly.

\section{Results}

\section{Efficacy of biopesticides against eggs of $B$. tabaci}

In 2017, a day before 1st spray, the eggs population of whiteflies ranged from 3.6 to 5.7 eggs per leaf showing non-significant difference among the evaluated treatments. After 1st spray, all the biopesticides significantly reduced egg population than in the untreated control. Among the 5 treatments, Malathion at $4.0 \mathrm{ml} / \mathrm{l}$ (76.8\%) exhibited the highest efficacy against the eggs of the whitefly. Among the biopesticides, Neem Baan (at 15 and $10 \mathrm{ml} / \mathrm{l}$ (63.7 and 59.8\%)) was efficacious, followed by the EPF; L. lecanii (at 15 and $10 \mathrm{ml} / \mathrm{l}$ (46.2 and 41.2\%)), B. bassiana (at 15 and $10 \mathrm{ml} / \mathrm{l}$ (45.5 and $41.8 \%)$ ), and $M$. anisopliae (at 15 and $10 \mathrm{ml} / \mathrm{l}$ (39.5 and $36.5 \%$ PROC)), respectively (Table 2$)\left(\right.$ Temp $_{\operatorname{Max}}=34.3$ ${ }^{\circ} \mathrm{C}$; Temp Min $\left.=17.3{ }^{\circ} \mathrm{C} ; \mathrm{RH}_{\mathrm{M}}=90 \% ; \mathrm{RH}_{\mathrm{E}}=32 \%\right)$. The percent reduction over control (PROC, progressively increased after subsequent sprays during the season. The PROC values of the 2nd spray ranged from $63.9 \%$ ( $M$. anisopliae at $10 \mathrm{ml} / \mathrm{l}$ ) to $87.6 \%$ (Malathion $50 \mathrm{EC}$ at 4.0 $\mathrm{ml} / \mathrm{l})\left(\mathrm{Temp}_{\operatorname{Max}}=28.0{ }^{\circ} \mathrm{C} ; \mathrm{Temp}_{\mathrm{Min}}=15.3{ }^{\circ} \mathrm{C} ; \mathrm{RH}_{\mathrm{M}}=\right.$ 91\%; $\left.\mathrm{RH}_{\mathrm{E}}=53 \%\right)$.

After the 3rd spray, Malathion at $4.0 \mathrm{ml} / \mathrm{l}$ and Neem Baan at $15 \mathrm{ml} / \mathrm{l}$ were statistically at par with each other ( 97.5 and $93.3 \%$ PROC), followed by Neem Baan at 10 $\mathrm{ml} / \mathrm{l}$ (90.7\% reduction). The lowest percent reduction in eggs was recorded in the case of $M$. anisopliae at $10 \mathrm{ml} / \mathrm{l}$ (78.4\% reduction) $\left(\mathrm{Temp}_{\operatorname{Max}}=22.3{ }^{\circ} \mathrm{C}\right.$; $\mathrm{Temp}_{\operatorname{Min}}=12.9$ ${ }^{\circ} \mathrm{C} ; \mathrm{RH}_{\mathrm{M}}=89 \% ; \mathrm{RH}_{\mathrm{E}}=60 \%$ ).

In 2018 , the mean whitefly egg population did not vary significantly (3.3 to 5.4 eggs per leaf) at 1 day before spraying (DBS) during autumn, 2018 season, indicating uniform distribution of the pest. After 1st spray, Malathion at $4.0 \mathrm{ml} / \mathrm{l}(77.5 \%)$ maintained its superiority over other treatments, followed by Neem Baan at $15 \mathrm{ml} / \mathrm{l}$ $(62.6 \%)$ and it was statistically at par with Neem Baan at $10 \mathrm{ml} / \mathrm{l}$ (59.3\% PROC). However, the lowest percent reduction in eggs was recorded in the case of $M$. anisopliae at $10 \mathrm{ml} / \mathrm{l}(37.7 \%)$ and it was also statistically at par with $B$. bassiana at $10 \mathrm{ml} / \mathrm{l}(42.1 \%)$, L. lecanii at $10 \mathrm{ml} / \mathrm{l}$ (41.3\%), and $M$. anisopliae at $15 \mathrm{ml} / \mathrm{l}$ (40.8\% PROC), respectively $\left(\right.$ Temp $_{\text {Max }}=26.2{ }^{\circ} \mathrm{C}$; Temp $p_{\text {Min }}=14.2{ }^{\circ} \mathrm{C}$; $\mathrm{RH}_{\mathrm{M}}$ $\left.=90 \% ; \mathrm{RH}_{\mathrm{E}}=35 \%\right)$. PROC values of the 2nd spray ranged from 61.6 to $89.8 \%$ for $M$. anisopliae at $10 \mathrm{ml} / \mathrm{l}$ and Malathion $50 \mathrm{EC}$, respectively $\left(\mathrm{Temp}_{\mathrm{Max}}=27.1{ }^{\circ} \mathrm{C}\right.$; $\mathrm{Temp}_{\text {Min }}=11.0{ }^{\circ} \mathrm{C} ; \mathrm{RH}_{\mathrm{M}}=90 \% ; \mathrm{RH}_{\mathrm{E}}=33 \%$ ).

After the 3rd spray, the maximum percent reduction in egg population of whitefly was recorded in Malathion at $4.0 \mathrm{ml} / \mathrm{l}(98.1 \%)$ and it was significantly better than the rest of the treatments. The lowest percent reduction was recorded in case of $M$. anisopliae at $10 \mathrm{ml} / \mathrm{l}(81.3 \%)$ and it was statistically at par

Table 2 Efficacy of different biopesticides against eggs of Bemisia tabaci on cucumber under net house conditions during autumn cropping season (2017)

\begin{tabular}{|c|c|c|c|c|c|}
\hline \multirow[t]{2}{*}{ Treatment } & \multirow[t]{2}{*}{$\begin{array}{l}\text { Concentrations } \\
(\mathrm{ml} / \mathrm{l})\end{array}$} & \multicolumn{4}{|c|}{$\begin{array}{l}\text { Percent reduction over control in eggs of Bemisia tabaci per leaf } *(\text { mean } \pm \mathrm{SE}) \\
\text { after different sprays }\end{array}$} \\
\hline & & 1st spray & 2nd spray & 3rd spray & Overall reduction (\%) \\
\hline \multirow[t]{2}{*}{ Beauveria bassiana $\left(1 \times 10^{9} \mathrm{CFU} / \mathrm{ml}\right)$} & 10 & $41.8 \pm 1.0^{e}$ & $66.3 \pm 1.8^{\text {ef }}$ & $80.6 \pm 0.3^{\mathrm{ef}}$ & $62.9 \pm 11.3^{\mathrm{a}}$ \\
\hline & 15 & $45.5 \pm 1.3^{d}$ & $70.4 \pm 0.4^{\text {de }}$ & $85.5 \pm 1.5^{\text {de }}$ & $67.1 \pm 11.7^{\mathrm{a}}$ \\
\hline \multirow[t]{2}{*}{ Lecanicillium lecanii $\left(1\right.$ × $\left.10^{9} \mathrm{CFU} / \mathrm{ml}\right)$} & 10 & $41.2 \pm 1.7^{\mathrm{e}}$ & $66.9 \pm 0.8^{\mathrm{ef}}$ & $82.9 \pm 2.3^{\text {def }}$ & $63.7 \pm 12.1^{\mathrm{a}}$ \\
\hline & 15 & $46.2 \pm 0.8^{d}$ & $72.8 \pm 1.7^{\mathrm{cd}}$ & $86.5 \pm 2.5^{c d}$ & $68.5 \pm 11.8^{\mathrm{a}}$ \\
\hline \multirow[t]{2}{*}{ Metarhizium anisopliae $\left(1 \times 10^{8} \mathrm{CFU} / \mathrm{ml}\right)$} & 10 & $36.5 \pm 0.9^{f}$ & $63.9 \pm 0.2^{f}$ & $78.4 \pm 0.7^{f}$ & $59.6 \pm 12.3^{\mathrm{a}}$ \\
\hline & 15 & $39.5 \pm 0.9^{e f}$ & $64.7 \pm 0.4^{f}$ & $82.4 \pm 1.7^{\text {def }}$ & $62.2 \pm 12.4^{\mathrm{a}}$ \\
\hline \multirow[t]{2}{*}{ Neem Baan (1\% W/W) } & 10 & $59.8 \pm 1.4^{c}$ & $77.2 \pm 0.9^{b c}$ & $90.7 \pm 1.0^{\mathrm{bc}}$ & $75.9 \pm 8.9^{a}$ \\
\hline & 15 & $63.7 \pm 0.7^{b}$ & $78.3 \pm 2.8^{b}$ & $93.3 \pm 2.3^{\mathrm{ab}}$ & $78.4 \pm 8.5^{\mathrm{a}}$ \\
\hline Malathion $50 \mathrm{EC}$ & 4.0 & $76.8 \pm 0.6^{\mathrm{a}}$ & $87.6 \pm 3.1^{\mathrm{a}}$ & $97.5 \pm 1.2^{\mathrm{a}}$ & $87.3 \pm 6.0^{\mathrm{a}}$ \\
\hline \multicolumn{2}{|l|}{$F$ values } & 151.1 & 21.4 & 14.2 & 0.7 \\
\hline \multicolumn{2}{|l|}{$P$} & $<0.001$ & $<0.001$ & $<0.001$ & 0.7 \\
\hline
\end{tabular}

Percent reduction over control mean \pm standard error of $B$. tabaci eggs recorded after different sprays for bioassays performed with different commercial strains. Treatment columns bearing different letters are significantly different from other treatments according to Duncan's multiple range test (DMRT) $(P=0.05)$. Range of pretreatment population eggs $=3.6$ to 5.7 eggs/leaf

*Values represent means of 3 replicates 
Table 3 Efficacy of different biopesticides against eggs of Bemisia tabaci on cucumber under net house conditions during autumn cropping season (2018)

\begin{tabular}{|c|c|c|c|c|c|}
\hline \multirow[t]{2}{*}{ Treatment } & \multirow[t]{2}{*}{$\begin{array}{l}\text { Concentrations } \\
(\mathrm{ml} / \mathrm{l})\end{array}$} & \multicolumn{4}{|c|}{$\begin{array}{l}\text { Percent reduction over control in eggs of Bemisia tabaci per leaf } *(\text { mean } \pm S E) \\
\text { after different sprays }\end{array}$} \\
\hline & & 1st spray & 2nd spray & 3rd spray & Overall reduction (\%) \\
\hline \multirow[t]{2}{*}{ Beauveria bassiana $\left(1 \times 10^{9} \mathrm{CFU} / \mathrm{ml}\right)$} & 10 & $42.1 \pm 2.2^{\text {cd }}$ & $65.1 \pm 0.7^{e}$ & $81.8 \pm 1.8^{c}$ & $63.0 \pm 11.5^{\mathrm{a}}$ \\
\hline & 15 & $46.5 \pm 0.4^{c}$ & $67.7 \pm 1.5^{\mathrm{de}}$ & $83.4 \pm 0.2^{c}$ & $65.9 \pm 10.7^{\mathrm{a}}$ \\
\hline \multirow[t]{2}{*}{ Lecanicillium lecanii $\left(1 \times 10^{9} \mathrm{CFU} / \mathrm{ml}\right)$} & 10 & $41.3 \pm 2.4^{\mathrm{cd}}$ & $65.6 \pm 1.3^{\mathrm{e}}$ & $83.0 \pm 0.3^{c}$ & $63.3 \pm 12.1^{\mathrm{a}}$ \\
\hline & 15 & $45.2 \pm 1.1^{c}$ & $72.0 \pm 1.2^{\text {cd }}$ & $85.1 \pm 3.0^{c}$ & $67.4 \pm 11.7^{\mathrm{a}}$ \\
\hline \multirow[t]{2}{*}{ Metarhizium anisopliae $\left(1 \times 10^{8} \mathrm{CFU} / \mathrm{ml}\right)$} & 10 & $37.7 \pm 0.7^{d}$ & $61.6 \pm 2.8^{e}$ & $81.3 \pm 1.5^{c}$ & $60.2 \pm 12.6^{a}$ \\
\hline & 15 & $40.8 \pm 1.7^{c d}$ & $64.0 \pm 1.0^{\mathrm{e}}$ & $82.8 \pm 1.7^{c}$ & $62.5 \pm 12.1^{\mathrm{a}}$ \\
\hline \multirow{2}{*}{$\begin{array}{l}\text { Neem Baan } \\
(1 \% \text { W/W })\end{array}$} & 10 & $59.3 \pm 2.3^{b}$ & $77.4 \pm 3.1^{b c}$ & $90.9 \pm 2.3^{b}$ & $75.9 \pm 9.2^{\mathrm{a}}$ \\
\hline & 15 & $62.6 \pm 3.9^{b}$ & $79.6 \pm 1.5^{b}$ & $92.4 \pm 2.0^{b}$ & $78.2 \pm 8.6^{\mathrm{a}}$ \\
\hline Malathion $50 \mathrm{EC}$ & 4.0 & $77.5 \pm 2.9^{a}$ & $89.8 \pm 2.8^{\mathrm{a}}$ & $98.1 \pm 1.9^{\mathrm{a}}$ & $88.5 \pm 6.0^{a}$ \\
\hline \multicolumn{2}{|l|}{$F$ values } & 35.5 & 22.2 & 10.2 & 0.8 \\
\hline \multicolumn{2}{|l|}{$P$} & $<0.001$ & $<0.001$ & $<0.001$ & 0.6 \\
\hline
\end{tabular}

Percent reduction over control mean \pm standard error of $B$. tabaci eggs recorded after different sprays for bioassays performed with different commercial strains. Treatment columns bearing different letters are significantly different from other treatments according to Duncan's multiple range test (DMRT) $(P=0.05)$. Range of pretreatment population eggs $=3.3$ to 5.4 eggs/leaf

*Values represent means of 3 replicates

with rest of the treatments viz., L. lecanii at 15 and $10 \mathrm{ml} / \mathrm{l}(85.1$ and $83.0 \%)$, B. bassiana at 15 and 10 $\mathrm{ml} / \mathrm{l}$ (83.4 and $81.8 \%$ ) and $M$. anisopliae at $15 \mathrm{ml} / \mathrm{l}$ $(82.8 \%)$, respectively $\left(\mathrm{Temp}_{\operatorname{Max}}=27.2^{\circ} \mathrm{C}\right.$; $\mathrm{Temp}_{\mathrm{Min}}=$ $10.8{ }^{\circ} \mathrm{C} ; \mathrm{RH}_{\mathrm{M}}=88 \% ; \mathrm{RH}_{\mathrm{E}}=31 \%$ ) (Table 3).

The pooled analysis of all the biopesticidal treatments after 3 sprays revealed that there was non-significant difference among the treatments in overall reduction (Table 2). Same trend was observed during autumn cropping season of 2018 (Table 3).

\section{Efficacy of biopesticides against nymphs of $B$. tabaci}

In 2017, the number of nymphs of B. tabaci per leaf was counted before the 1st spray and the mean nymph incidence, 1 day before 1st spray, indicated non-significant differences among all the treatments and the mean nymphs populations ranged from 14.3 to 19.3 nymphs per leaf. In the observations recorded after 1st spray, among the different treatments, Malathion at $4.0 \mathrm{ml} / \mathrm{l} \mathrm{re}$ corded the highest population reduction of nymphs of $B$. tabaci (75.6\%). It was significantly superior to other biopesticidal treatments. The 2 nd best treatment was Neem Baan at 15 and $10 \mathrm{ml} / \mathrm{l}$ (65.5 and 60.5\% PROC). However, the treatments with the EPF; L. lecanii (at 15 and $10 \mathrm{ml} / \mathrm{l}(51.6$ and 49.7\%)), B. bassiana (at 15 and $10 \mathrm{ml} / \mathrm{l}$ (50.2 and 48.6\%)), and M. anisopliae (at 15 and $10 \mathrm{ml} / \mathrm{l}$ (48.6 and 46.1\%)) were found statistically at par with each other $($ Table 4$)\left(\mathrm{Temp}_{\operatorname{Max}}=34.3{ }^{\circ} \mathrm{C}\right.$; $\mathrm{Temp}_{\text {Min }}=$ $\left.17.3^{\circ} \mathrm{C} ; \mathrm{RH}_{\mathrm{M}}=90 \% ; \mathrm{RH}_{\mathrm{E}}=32 \%\right)$.

Malathion (at $4.0 \mathrm{ml} / \mathrm{l}(99.0 \%)$ ), Neem Baan (at 15 and $10 \mathrm{ml} / 1$ (96.3 and 93.3\%)), L. lecanii (at 15 and $10 \mathrm{ml} / \mathrm{l}$ (91.5 and 90.1\%)), and B. bassiana (at $15 \mathrm{ml} / \mathrm{l}(91.2 \%)$ ) were the most effective in population reduction of whitefly nymphs whereas B. bassiana (at $10 \mathrm{ml} / \mathrm{l}$ (89.0\%)) and $M$. anisopliae (at $15 \mathrm{ml} / \mathrm{l}(85.0 \%)$ ) were moderate, while $M$. anisopliae (at $10 \mathrm{ml} / \mathrm{l}$ (82.5\% PROC)) was found comparatively less effective in reducing the population of whitefly nymphs after the 3rd spray $\left(\right.$ Temp $_{\text {Max }}=22.3{ }^{\circ} \mathrm{C}$; Temp $p_{\text {Min }}=12.9{ }^{\circ} \mathrm{C} ; \mathrm{RH}_{\mathrm{M}}=89 \%$; $\mathrm{RH}_{\mathrm{E}}=60 \%$ ).

In 2018, the mean population of nymph whiteflies 1 day before of 1st spray ranged between 14.9 and 18.0 nymphs per leaf and showed non-significant uniform distribution of nymphal population in all treatment plots of the field experiment. After 1st spray, Malathion at 4.0 $\mathrm{ml} / \mathrm{l}$ was the most effective in reducing the nymphs of whiteflies (77.7\% reduction). However, it was statistically at par with Neem Baan at 15 and $10 \mathrm{ml} / \mathrm{l}$ (62.5 and $57.8 \%$ reduction), $L$. lecanii at $15 \mathrm{ml} / \mathrm{l}$ (50.6\% reduction), and $B$. bassiana $15 \mathrm{ml} / \mathrm{l}$ (48.2\% reduction), respectively. The lowest percent reduction was recorded in the treatment of $M$. anisopliae at $10 \mathrm{ml} / \mathrm{l}(41.6 \%$ reduction) and it was also statistically at par with M. anisopliae at 15 $\mathrm{ml} / \mathrm{l}$ (46.1\% reduction), L. lecanii at $10 \mathrm{ml} / \mathrm{l}(46.0 \%$ reduction), and B. bassiana at $10 \mathrm{ml} / \mathrm{l}(46.0 \%$ reduction), respectively $($ Table 5$)\left(\mathrm{Temp}_{\text {Max }}=26.2{ }^{\circ} \mathrm{C}\right.$; $\mathrm{Temp}_{\text {Min }}=$ $\left.14.2{ }^{\circ} \mathrm{C} ; \mathrm{RH}_{\mathrm{M}}=90 \% ; \mathrm{RH}_{\mathrm{E}}=35 \%\right)$.

After 3rd spray, Malathion at $4.0 \mathrm{ml} / \mathrm{l}$ was found most effective in terms of percent reduction of nymphs of whitefly (99.5\% reduction), followed by Neem Baan (at 15 and $10 \mathrm{ml} / 1$ (97.1 and 94.5\%)), L. lecanii (at $15 \mathrm{ml} / \mathrm{l}$ $(91.1 \%)$ ), and B. bassiana (at $15 \mathrm{ml} / \mathrm{l}$ (89.9\%), respectively, while $M$. anisopliae at $10 \mathrm{ml} / \mathrm{l}$ was found least effective one (83.8\% reduction). It was statistically at par 
Table 4 Efficacy of different biopesticides against nymphs of Bemisia tabaci on cucumber under net house conditions during autumn cropping season (2017)

\begin{tabular}{|c|c|c|c|c|c|}
\hline \multirow[t]{2}{*}{ Treatment } & \multirow[t]{2}{*}{$\begin{array}{l}\text { Concentrations } \\
(\mathrm{ml} / \mathrm{l})\end{array}$} & \multicolumn{4}{|c|}{$\begin{array}{l}\text { Percent reduction over control in nymphs of Bemisia tabaci per leaf } *(\text { mean } \pm S E) \\
\text { after different sprays }\end{array}$} \\
\hline & & 1st spray & 2nd spray & 3rd spray & Overall reduction (\%) \\
\hline \multirow[t]{2}{*}{ Beauveria bassiana $\left(1 \times 10^{9} \mathrm{CFU} / \mathrm{ml}\right)$} & 10 & $48.6 \pm 2.9^{c}$ & $72.1 \pm 2.6^{\text {de }}$ & $88.9 \pm 2.2^{\mathrm{cd}}$ & $69.9 \pm 11.7^{\mathrm{a}}$ \\
\hline & 15 & $50.2 \pm 2.4^{c}$ & $76.4 \pm 2.7^{c d}$ & $91.2 \pm 2.6^{\mathrm{bcd}}$ & $72.6 \pm 12.0^{\mathrm{a}}$ \\
\hline \multirow[t]{2}{*}{ Lecanicillium lecanii $\left(1 \times 10^{9} \mathrm{CFU} / \mathrm{ml}\right)$} & 10 & $49.7 \pm 1.6^{c}$ & $74.1 \pm 2.9^{\text {de }}$ & $90.1 \pm 2.0^{b c d}$ & $71.3 \pm 11.7^{\mathrm{a}}$ \\
\hline & 15 & $51.6 \pm 1.1^{c}$ & $77.5 \pm 1.8^{\mathrm{bcd}}$ & $91.5 \pm 2.2^{\mathrm{bcd}}$ & $73.5 \pm 11.7^{\mathrm{a}}$ \\
\hline \multirow[t]{2}{*}{ Metarhizium anisopliae $\left(1 \times 10^{8} \mathrm{CFU} / \mathrm{ml}\right)$} & 10 & $46.1 \pm 1.7^{c}$ & $68.2 \pm 2.8^{\mathrm{e}}$ & $82.5 \pm 3.3^{e}$ & $65.6 \pm 10.6^{\mathrm{a}}$ \\
\hline & 15 & $48.6 \pm 4.0^{c}$ & $71.4 \pm 1.9^{\mathrm{de}}$ & $85.0 \pm 2.0^{\mathrm{de}}$ & $68.3 \pm 10.6^{\mathrm{a}}$ \\
\hline \multirow[t]{2}{*}{ Neem Baan (1\% W/W) } & 10 & $60.5 \pm 5.4^{b}$ & $81.9 \pm 3.2^{b c}$ & $93.3 \pm 1.5^{\mathrm{abc}}$ & $78.6 \pm 9.6^{\mathrm{a}}$ \\
\hline & 15 & $65.5 \pm 1.7^{\mathrm{b}}$ & $84.2 \pm 0.9^{b}$ & $96.3 \pm 0.7^{\mathrm{ab}}$ & $82.0 \pm 9.0^{\mathrm{a}}$ \\
\hline Malathion $50 \mathrm{EC}$ & 4.0 & $75.6 \pm 0.4^{\mathrm{a}}$ & $91.2 \pm 0.9^{\mathrm{a}}$ & $99.0 \pm 0.5^{\mathrm{a}}$ & $88.6 \pm 6.9^{a}$ \\
\hline$F$ values & & 13.0 & 9.7 & 6.2 & 0.5 \\
\hline$P$ & & $<0.001$ & $<0.001$ & 0.001 & 0.9 \\
\hline
\end{tabular}

Percent reduction over control mean \pm standard error of $B$. tabaci nymphs recorded after different sprays for bioassays performed with different commercial strains. Treatment columns bearing different letters are significantly different from other treatments according to Duncan's multiple range test $(D M R T)(P=0.05)$. Range of pretreatment population nymphs $=14.3$ to 19.3 nymphs/leaf

*Values represent means of 3 replicates

with $M$. anisopliae at $15 \mathrm{ml} / \mathrm{l}$ (85.9\% reduction), B. bassiana at $10 \mathrm{ml} / \mathrm{l}$ (85.8\% reduction), and L. lecanii at $10 \mathrm{ml} /$ l $\left(85.7 \%\right.$ reduction), respectively $\left(\right.$ Temp $p_{\text {Max }}=27.2{ }^{\circ} \mathrm{C}$; $\left.\mathrm{Temp}_{\text {Min }}=10.8{ }^{\circ} \mathrm{C} ; \mathrm{RH}_{\mathrm{M}}=88 \% ; \mathrm{RH}_{\mathrm{E}}=31 \%\right)($ Table 5$)$.

The pooled analysis of the 3 sprays for overall reduction of $B$. tabaci nymphs revealed that among all the treatments, Malathion at $4.0 \mathrm{ml} / \mathrm{l}$ gave maximum reduction in nymphs of B. tabaci $(88.6 \%)$ and it was statistically at par to all other biopesticidal treatments (Table
4). Similar trend was observed during autumn cropping season of 2018 (Table 5).

\section{Efficacy of biopesticides against adults of $B$. tabaci}

In 2017, the variation in the pre-treatment population on adults of $B$. tabaci in different treatments was statistically non-significant, indicating that the population was uniformly distributed in the net house before the different treatments were imposed. The mean population of

Table 5 Efficacy of different biopesticides against nymphs of Bemisia tabaci on cucumber under net house conditions during autumn cropping season (2018)

\begin{tabular}{|c|c|c|c|c|c|}
\hline \multirow[t]{2}{*}{ Treatment } & \multirow[t]{2}{*}{$\begin{array}{l}\text { Concentrations } \\
(\mathrm{ml} / \mathrm{l})\end{array}$} & \multicolumn{4}{|c|}{$\begin{array}{l}\text { Percent reduction over control in nymphs of Bemisia tabaci per leaf }{ }^{*}(\text { mean } \pm S E) \\
\text { after different sprays }\end{array}$} \\
\hline & & 1st spray & 2nd spray & 3rd spray & Overall reduction (\%) \\
\hline \multirow[t]{2}{*}{ Beauveria bassiana $\left(1 \times 10^{9} \mathrm{CFU} / \mathrm{ml}\right)$} & 10 & $46.0 \pm 4.3^{b}$ & $69.3 \pm 3.5^{d}$ & $85.8 \pm 3.6^{c}$ & $67.0 \pm 11.5^{a}$ \\
\hline & 15 & $48.2 \pm 5.9^{\mathrm{ab}}$ & $73.8 \pm 2.1^{\mathrm{bcd}}$ & $89.9 \pm 2.2^{b c}$ & $70.6 \pm 12.1^{a}$ \\
\hline \multirow[t]{2}{*}{ Lecanicillium lecanii $\left(1 \times 10^{9} \mathrm{CFU} / \mathrm{ml}\right)$} & 10 & $46.0 \pm 6.9^{b}$ & $70.5 \pm 4.0^{\mathrm{cd}}$ & $85.7 \pm 2.6^{c}$ & $67.4 \pm 11.6^{a}$ \\
\hline & 15 & $50.6 \pm 4.6^{a b}$ & $75.3 \pm 2.8^{\mathrm{bcd}}$ & $91.1 \pm 2.6^{b c}$ & $72.3 \pm 11.8^{a}$ \\
\hline \multirow[t]{2}{*}{ Metarhizium anisopliae $\left(1 \times 10^{8} \mathrm{CFU} / \mathrm{ml}\right)$} & 10 & $41.6 \pm 9.8^{b}$ & $65.5 \pm 3.7^{d}$ & $83.8 \pm 0.6^{c}$ & $63.6 \pm 12.2^{a}$ \\
\hline & 15 & $46.1 \pm 8.7^{b}$ & $67.3 \pm 4.4^{d}$ & $85.9 \pm 4.3^{c}$ & $66.4 \pm 11.5^{a}$ \\
\hline \multirow[t]{2}{*}{ Neem Baan (1\% W/W) } & 10 & $57.8 \pm 6.5^{a b}$ & $79.8 \pm 2.0^{\mathrm{bc}}$ & $94.5 \pm 1.8^{a b}$ & $77.4 \pm 10.7^{a}$ \\
\hline & 15 & $62.5 \pm 6.4^{a b}$ & $83.0 \pm 1.6^{a b}$ & $97.1 \pm 1.0^{a b}$ & $80.9 \pm 10.0^{a}$ \\
\hline Malathion $50 \mathrm{EC}$ & 4.0 & $77.7 \pm 0.4^{a}$ & $90.3 \pm 1.9^{a}$ & $99.5 \pm 0.5^{a}$ & $89.2 \pm 6.3^{a}$ \\
\hline$F$ values & & 3.1 & 7.0 & 5.2 & 0.6 \\
\hline$P$ & & 0.23 & $<0.001$ & 0.002 & 0.8 \\
\hline
\end{tabular}

Percent reduction over control mean \pm standard error of $B$. tabaci nymphs recorded after different sprays for bioassays performed with different commercial strains. Treatment columns bearing different letters are significantly different from other treatments according to Duncan's multiple range test $(D M R T)(P=0.05)$. Range of pretreatment population nymphs $=14.9$ to 18.0 nymphs/leaf

*Values represent means of 3 replicates 
B. tabaci, 1 day before imposing the treatments, was from 5.9 to 7.1 adults per 3 leaves.

All the treatments were significantly superior to the untreated control in adults of B. tabaci after 1st, 2nd, and 3rd spray. The highest population reduction over control after the 2nd spray was recorded in Malathion at $4.0 \mathrm{ml} / \mathrm{l}(88.7 \%)$. However, it was statistically at par with Neem Baan at 15 and $10 \mathrm{ml} / \mathrm{l}(87.0$ and $83.9 \%$ reduction). The 2nd best treatment was by L. lecanii (at 15 and $10 \mathrm{ml} / \mathrm{l}$ (54.5 and 50.5\%). It was also statistically at par with other biopesticidal treatments viz., B. bassiana (at 15 and $10 \mathrm{ml} / 1$ (50.7 and $47.8 \%$ PROC) and $M$. anisopliae (at 15 and $10 \mathrm{ml} / \mathrm{l}$ (45.7 and 46.3\% PROC), respectively $\left(\right.$ Temp $_{\text {Max }}=28.0{ }^{\circ} \mathrm{C}$; Temp Min $_{\text {Min }}=15.3^{\circ} \mathrm{C} ; \mathrm{RH}_{\mathrm{M}}$ $\left.=91 \% ; \mathrm{RH}_{\mathrm{E}}=53 \%\right)$. Same trend was observed after the 3rd spray and in overall reduction of different biopesticidal treatments, respectively (Table 6).

In 2018, the pre-treatment population of adult whiteflies was uniform in all the experimental treatment plots, since the average population of adults was statistically non-significant. The average pre-treatment population ranged between 5.8 and 7.4 adults per 3 leaves justifying that there was a need to protect the crop from whiteflies infestation.

The data recorded after the 1st spray revealed that population reduction of adults ranged from 36.3 to $77.1 \%$ in different treatments. All the biopesticidal treatments were found significantly superior over control in reducing the population of adults. Malathion at $4.0 \mathrm{ml} / 1$ ( $77.1 \%$ reduction) was found superior than the other treatments in reducing the population of adults. Neem Baan at 15 and $10 \mathrm{ml} / \mathrm{l}$ (61.9 and 59.1\% PROC) was found the next best treatment as compared to the rest of the treatments $\left(\mathrm{Temp}_{\mathrm{Max}}=26.2{ }^{\circ} \mathrm{C}\right.$; $\mathrm{Temp}_{\text {Min }}=14.2{ }^{\circ} \mathrm{C}$; $\left.\mathrm{RH}_{\mathrm{M}}=90 \% ; \mathrm{RH}_{\mathrm{E}}=35 \%\right)$.

After 2nd spray, highest population reduction of adults was observed in the plots treated with Malathion at 4.0 $\mathrm{ml} / \mathrm{l}$ (91.0\% reduction) and found most effective in reducing the population of adults, followed by Neem Baan at 15 and $10 \mathrm{ml} / \mathrm{l}$ (85.2 and $82.6 \%$ reduction), which was statistically at par with each other. However, the treatments L. lecanii (at 15 and $10 \mathrm{ml} / 1$ (56.7 and 53.4\% PROC)), B. bassiana (at 15 and $10 \mathrm{ml} / 1$ (51.7 and 51.6\% PROC)), and $M$. anisopliae (at 15 and $10 \mathrm{ml} / 1$ (49.2 and $47.9 \%$ PROC)) were found statistically at par amongst each other though significantly poorer than Neem Baan and Malathion $\left(\mathrm{Temp}_{\operatorname{Max}}=27.1{ }^{\circ} \mathrm{C}\right.$; $\mathrm{Temp}_{\text {Min }}=11.0{ }^{\circ} \mathrm{C}$; $\left.\mathrm{RH}_{\mathrm{M}}=90 \% ; \mathrm{RH}_{\mathrm{E}}=33 \%\right)$. After 3rd spray also, similar trend was observed (Table 7).

The pooled data for overall reduction in population of adult whitefly also showed that the treatment Malathion at $4.0 \mathrm{ml} / \mathrm{l}$ gave maximum reduction in adults of $B$. tabaci (89.0\% reduction). However, it was statistically at par with Neem Baan at 15 and $10 \mathrm{ml} / \mathrm{l}(80.4$ and $78.0 \%$ reduction). $M$. anisopliae at $10 \mathrm{ml} / \mathrm{l}$ gave the lowest reduction (48.2\%) and it was also statistically at par with the rest of the treatments (Table 7).

\section{Marketable fruit yield}

The cumulative marketable yield of cucumber in different treatments given for the management of $B$. tabaci infestation under net house condition (Table 8) varied from 2120.8 to $2468.8 \mathrm{~g}$ per plant in 2017 and 2137.5 to $2541.7 \mathrm{~g}$ per plant in 2018 cropping seasons. In 2017,

Table 6 Efficacy of different biopesticides against adults of Bemisia tabaci on cucumber under net house conditions during autumn cropping season (2017)

\begin{tabular}{|c|c|c|c|c|c|}
\hline \multirow[t]{2}{*}{ Treatment } & \multirow[t]{2}{*}{$\begin{array}{l}\text { Concentrations } \\
(\mathrm{ml} / \mathrm{l})\end{array}$} & \multicolumn{4}{|c|}{$\begin{array}{l}\text { Percent reduction over control in adults of Bemisia tabaci per three leaves * (mean } \\
\pm \mathrm{SE}) \text { after different sprays }\end{array}$} \\
\hline & & 1st spray & 2nd spray & 3rd spray & Overall reduction (\%) \\
\hline \multirow[t]{2}{*}{ Beauveria bassiana $\left(1 \times 10^{9} \mathrm{CFU} / \mathrm{ml}\right)$} & 10 & $36.3 \pm 7.8^{d}$ & $47.8 \pm 8.2^{b}$ & $58.5 \pm 6.7^{b}$ & $47.5 \pm 6.4^{b}$ \\
\hline & 15 & $41.5 \pm 6.6^{\mathrm{bcd}}$ & $50.7 \pm 5.8^{b}$ & $62.3 \pm 3.3^{b}$ & $51.5 \pm 6.0^{b}$ \\
\hline \multirow[t]{2}{*}{ Lecanicillium lecanii $\left(1 \times 10^{9} \mathrm{CFU} / \mathrm{ml}\right)$} & 10 & $40.8 \pm 6.4^{\mathrm{bcd}}$ & $50.5 \pm 9.5^{b}$ & $64.9 \pm 3.4^{b}$ & $52.1 \pm 7.0^{b}$ \\
\hline & 15 & $45.4 \pm 7.8^{\mathrm{bcd}}$ & $54.5 \pm 7.3^{b}$ & $66.7 \pm 6.8^{b}$ & $55.5 \pm 6.2^{b}$ \\
\hline \multirow[t]{2}{*}{ Metarhizium anisopliae $\left(1 \times 10^{8} \mathrm{CFU} / \mathrm{ml}\right)$} & 10 & $35.6 \pm 9.3^{d}$ & $46.3 \pm 8.8^{b}$ & $57.9 \pm 11.0^{\mathrm{b}}$ & $46.6 \pm 6.4^{b}$ \\
\hline & 15 & $39.8 \pm 10.5^{\mathrm{cd}}$ & $45.7 \pm 12.2^{b}$ & $57.7 \pm 11.8^{\mathrm{b}}$ & $47.7 \pm 5.3^{b}$ \\
\hline \multirow[t]{2}{*}{ Neem Baan (1\% W/W) } & 10 & $61.0 \pm 3.3^{\mathrm{abc}}$ & $83.9 \pm 3.7^{\mathrm{a}}$ & $93.1 \pm 1.8^{\mathrm{a}}$ & $79.3 \pm 9.5^{\mathrm{a}}$ \\
\hline & 15 & $63.0 \pm 4.0^{\mathrm{ab}}$ & $87.0 \pm 1.0^{\mathrm{a}}$ & $94.0 \pm 1.6^{\mathrm{a}}$ & $81.3 \pm 9.4^{\mathrm{a}}$ \\
\hline Malathion 50 EC & 4.0 & $74.1 \pm 3.2^{\mathrm{a}}$ & $88.7 \pm 3.8^{\mathrm{a}}$ & $98.4 \pm 1.2^{\mathrm{a}}$ & $87.1 \pm 7.1^{\mathrm{a}}$ \\
\hline$F$ values & & 3.9 & 6.4 & 7.0 & 5.3 \\
\hline$P$ & & 0.008 & 0.001 & $<0.001$ & 0.002 \\
\hline
\end{tabular}

Percent reduction over control mean \pm standard error of $B$. tabaci adults recorded after different sprays for bioassays performed with different commercial strains. Treatment columns bearing different letters are significantly different from other treatments according to Duncan's multiple range test (DMRT) $(P=0.05)$. Range of pretreatment population adults $=5.9$ to 7.1 adults $/ 3$ leaves

*Values represent means of 3 replicates 
Table 7 Efficacy of different biopesticides against adults of Bemisia tabaci on cucumber under net house conditions during autumn cropping season (2018)

\begin{tabular}{|c|c|c|c|c|c|}
\hline \multirow[t]{2}{*}{ Treatment } & \multirow[t]{2}{*}{$\begin{array}{l}\text { Concentrations } \\
(\mathrm{ml} / \mathrm{l})\end{array}$} & \multicolumn{4}{|c|}{$\begin{array}{l}\text { Percent reduction over control in adults of Bemisia tabaci per three leaves * (mean } \\
\pm \mathrm{SE}) \text { after different sprays }\end{array}$} \\
\hline & & 1st spray & 2nd spray & 3rd spray & Overall reduction (\%) \\
\hline \multirow[t]{2}{*}{ Beauveria bassiana $\left(1 \times 10^{9} \mathrm{CFU} / \mathrm{ml}\right)$} & 10 & $40.0 \pm 3.2^{c}$ & $51.6 \pm 4.7^{b}$ & $61.4 \pm 6.7^{b}$ & $51.0 \pm 6.2^{c}$ \\
\hline & 15 & $43.6 \pm 1.8^{c}$ & $51.7 \pm 10.4^{b}$ & $65.4 \pm 1.1^{\mathrm{b}}$ & $53.6 \pm 6.4^{c}$ \\
\hline \multirow[t]{2}{*}{ Lecanicillium lecanii $\left(1 \times 10^{9} \mathrm{CFU} / \mathrm{ml}\right)$} & 10 & $40.5 \pm 2.1^{c}$ & $53.4 \pm 5.8^{\mathrm{b}}$ & $64.6 \pm 7.1^{b}$ & $52.8 \pm 7.0^{c}$ \\
\hline & 15 & $45.3 \pm 2.3^{c}$ & $56.7 \pm 3.4^{b}$ & $69.2 \pm 4.3^{b}$ & $57.1 \pm 6.9^{\mathrm{bc}}$ \\
\hline \multirow[t]{2}{*}{ Metarhizium anisopliae $\left(1 \times 10^{8} \mathrm{CFU} / \mathrm{ml}\right)$} & 10 & $36.3 \pm 1.2^{c}$ & $47.9 \pm 2.6^{b}$ & $60.3 \pm 5.2^{b}$ & $48.2 \pm 6.9^{c}$ \\
\hline & 15 & $40.0 \pm 1.9^{c}$ & $49.2 \pm 5.2^{b}$ & $62.8 \pm 5.8^{\mathrm{b}}$ & $50.7 \pm 6.6^{c}$ \\
\hline \multirow[t]{2}{*}{ Neem Baan (1\% W/W) } & 10 & $59.1 \pm 5.7^{b}$ & $82.6 \pm 1.2^{\mathrm{a}}$ & $92.4 \pm 0.2^{a}$ & $78.0 \pm 9.9^{\mathrm{ab}}$ \\
\hline & 15 & $61.9 \pm 6.0^{b}$ & $85.2 \pm 1.4^{a}$ & $94.2 \pm 2.2^{a}$ & $80.4 \pm 9.6^{a}$ \\
\hline Malathion 50 EC & 4.0 & $77.1 \pm 2.4^{\mathrm{a}}$ & $91.0 \pm 0.8^{a}$ & $98.9 \pm 1.1^{a}$ & $89.0 \pm 6.4^{a}$ \\
\hline$F$ values & & 16.4 & 12.9 & 12.5 & 4.4 \\
\hline$P$ & & $<0.001$ & $<0.001$ & $<0.001$ & 0.004 \\
\hline
\end{tabular}

Percent reduction over control mean \pm standard error of $B$. tabaci adults recorded after different sprays for bioassays performed with different commercial strains. Treatment columns bearing different letters are significantly different from other treatments according to Duncan's multiple range test (DMRT) ( $P=0.05)$. Range of pretreatment population adults $=5.8$ to 7.4 adults/3 leaves

*Values represent means of 3 replicates

cropping season, Malathion at $4.0 \mathrm{ml} / \mathrm{l}$ resulted in the highest yield (2468.8 g per plant), followed by Neem Baan (at 15 and $10 \mathrm{ml} / \mathrm{l}(2381.3$ and $2337.5 \mathrm{~g}$ per plant)) and L. lecanii (at $15 \mathrm{ml} / \mathrm{l}$ (2210.4 g per plant)), being statistically at par to each other. The minimum marketable yield was recorded in case of $M$. anisopliae (at 15 and $10 \mathrm{ml} / \mathrm{l}$ (2131.3 and $2120.8 \mathrm{~g}$ per plant)), which was also statistically at par to B. bassiana (at 15 and $10 \mathrm{ml} / \mathrm{l}$ (2176.7 and $2137.5 \mathrm{~g}$ per plant)) and L. lecanii (at $10 \mathrm{ml} / \mathrm{l}$ (2150.0 g per plant)), respectively. The control treatment resulted in a fruit yield of $1802.1 \mathrm{~g}$ per plant, which was significantly lower than all the other treatments.

Whereas, in 2018, also in Malathion (at $4.0 \mathrm{ml} / \mathrm{l}$ ) and Neem Baan (at 15 and $10 \mathrm{ml} / \mathrm{l}$ ) resulted to the maximum fruit yields of $2541.7,2420.8$, and $2375.0 \mathrm{~g}$ per plant and these yields were significantly superior to the rest of the treatments, respectively. The yields recorded in all other treatments varied from 2268.8 to $2164.6 \mathrm{~g}$ per plant which were statistically at par amongst the treatments. Minimum yield of $1827.1 \mathrm{~g}$ per plant was recorded in

Table 8 Marketable yield of parthenocarpic cucumber in different biopesticidal treatments against Bemisia tabaci during autumn cropping seasons

\begin{tabular}{|c|c|c|c|}
\hline \multirow[t]{2}{*}{ Treatment } & \multirow{2}{*}{$\begin{array}{l}\text { Concentrations } \\
(\mathrm{ml} / \mathrm{l})\end{array}$} & \multicolumn{2}{|c|}{ Yield (g/plant \pm SE) } \\
\hline & & 2017 & 2018 \\
\hline \multirow[t]{2}{*}{ Beauveria bassiana $\left(1 \times 10^{9} \mathrm{CFU} / \mathrm{ml}\right)$} & 10 & $2137.5 \pm 124.5^{b}$ & $2170.8 \pm 57.1^{d}$ \\
\hline & 15 & $2176.7 \pm 58.5^{\mathrm{b}}$ & $2235.4 \pm 70.7^{c d}$ \\
\hline \multirow[t]{2}{*}{ Lecanicillium lecanii $\left(1 \times 10^{9} \mathrm{CFU} / \mathrm{ml}\right)$} & 10 & $2150.0 \pm 13.0^{\mathrm{b}}$ & $2212.5 \pm 62.6^{\mathrm{cd}}$ \\
\hline & 15 & $2210.4 \pm 67.0^{a b}$ & $2268.8 \pm 77.6^{\mathrm{bcc}}$ \\
\hline \multirow[t]{2}{*}{ Metarhizium anisopliae $\left(1 \times 10^{8} \mathrm{CFU} / \mathrm{ml}\right.$} & 10 & $2120.8 \pm 132.4^{b}$ & $2137.5 \pm 49.6^{d}$ \\
\hline & 15 & $2131.3 \pm 130.0^{b}$ & $2164.6 \pm 47.1^{d}$ \\
\hline \multirow[t]{2}{*}{ Neem Baan (1\% W/W) } & 10 & $2337.5 \pm 57.3^{\mathrm{ab}}$ & $2375.0 \pm 39.0^{\mathrm{abc}}$ \\
\hline & 15 & $2381.3 \pm 61.3^{\mathrm{ab}}$ & $2420.8 \pm 38.9^{\mathrm{ab}}$ \\
\hline Malathion 50 EC & 4.0 & $2468.8 \pm 58.1^{\mathrm{a}}$ & $2541.7 \pm 19.9^{\mathrm{a}}$ \\
\hline Control (Untreated) & & $1802.1 \pm 38.6^{c}$ & $1827.1 \pm 61.1^{\mathrm{e}}$ \\
\hline$F$ values & & 4.8 & 12.4 \\
\hline$P$ & & 0.002 & $<0.001$ \\
\hline
\end{tabular}

Treatment columns bearing different letters are significantly different from other treatments according to Duncan's multiple range test (DMRT) $(P=0.05)$ 
the control plot (Table 8) and it was significantly lower than all the other biopesticidal treatments.

The effectiveness of neem-based biopesticides has been demonstrated worldwide in both open field and protected conditions. In open field conditions, it is being widely practiced that neem-based biopesticides are applied for management during early season when the infestation/population load is less. Neem as NSKE, Neem oil, and Crude extracts have been used by many workers. Greenhouse whitefly, T. vaporariorum, nymphs and adults can be successfully managed on cucumber, sweet pepper, and tomato by Neem Azal - T/S (Azadirachtin A1 \%) under greenhouse protected conditions (Sood et al. 2006; Prijović et al. 2012 and Kashyap 2013). Azadirachtin 1\% (at 4 and $5 \mathrm{ml} / \mathrm{l}$ ) results in $68.5-71.0 \%$ reduction in population of whitefly on capsicum under net house condition (Singh and Joshi 2020). Neem oil (1-3\%) and NSKE (3, 5, and 7\%) reduced considerably the population of cotton whitefly (Jat and Jeyakumar 2006). It has also been reported by many workers that the neem-based botanicals are more efficacious against egg and nymphal stages of whitefly as compared to adults.

\section{Discussion}

The present study supports this contention. Neem Baan $1 \%$ showed a high efficacy against eggs and nymphs. The highest emphasis is being laid on production of residuefree crop for better economic returns. The growing of crops in net houses (both off season and main season) for better quality insect-disease-free produce requires the use of entomopathogens. The potential of entomopathogens against Aleyrodidae is well established in high humidity warm conditions. The development of Aleyrodidae is aided by the suitable microclimatic condition under net houses. The efficacy of L. lecanii, B. bassiana, and $M$. anisopliae was well document (Torrado-Leon et al. 2006; Daniel and Wyss 2010).

The present study showed also that the EPF foliar spray resulted in 40 to $72 \%$ reduction of eggs, nymphs, and adults of whitefly infesting cucumber under poly net house conditions. For a stable management of whitefly, 3 sprays at 10 -day intervals, starting at 35 days after transplanting of cucumber was appropriate. Numerous studies used L. lecanii, B. bassiana, M. anisopliae, Paecilomyces fumosoroseus (Wize), and Lecanicillium muscarium as entomopathogens for the management of whiteflies in field as well as net house crops. L. lecanii was efficacious ( $86 \%$ mortality) against B. tabaci on brinjal (Phadke and Phadke 2000); silver leaf whitefly, $B$. argentifolii (Gindin et al. 2000); and cotton whitefly (26.6 to $76.6 \%$ mortality) after 7 days post treatment when applied at the concentration of $1 \times 10^{7}$ conidia $/ \mathrm{ml}$ (Scorsetti et al. 2008). Cuthbertson and Walters (2005) demonstrated the high pathogenicity of $L$. muscarium against 2nd instar larvae of sweet potato whitefly, $B$. tabaci, under laboratory and glasshouse conditions. $B$. bassiana isolate (Bb-01) proved effective against $B$. tabaci on Gossypium hirsutum, Lycopersicum esculentum, Solanum melongena, and Capsicum annum. It resulted in the mortality of eggs $(65.30 \%)$ and nymphs $(88.82 \%)$ with $\mathrm{LC}_{50}$ value $\left(2.7 \times 10^{6}\right.$ spores $\left./ \mathrm{ml}\right)$ and $\mathrm{LT}_{50}$ value $\left(2.0 \times 10^{8}\right)$ on G. hirsutum in comparison to other hosts (Zafar et al. 2016). B. bassiana showed a potential for management of whitefly both in green house and field crops (Liu and Stansly 2000 and Faria and Wraight 2001). Its effectiveness against 2 nd and 4 th instars of $B$. tabaci nymphs was reported on tomato and verbena (Quesada-Moraga et al. 2006). The nymphs of T. vaporariorum are highly susceptible to infection by $B$. bassiana on cucumber (Poprawski et al. 2000).

Sharma et al. (2015) evaluated different biopesticidal formulations against whitefly, B. tabaci, on tomato plants to control nymphs of tobacco whitefly, B. tabaci. Bio Magic (91.64\%), Mealikil (93.55\%), and Bio Power (88.91) were highly effective in reducing the nymphal whitefly population after 3 sprays. This is in concurrence with our study, wherein, both L. lecanii (Bio-Catch) and $B$. bassiana (Bio-Power) were recorded to be effective against $B$. tabaci on cucumber in net house conditions.

Sharma et al. (2015) evaluated the bio-pesticides (Lastraw, Racer $^{\mathrm{TM}}$, Pacer ${ }^{\mathrm{TM}}$, Mealikil ${ }^{\mathrm{TM}}$, Nimbecidine, Servo, Biocide Manic, Bio Power, Nico Neem, Uchit, MightyCure, and Bio Magic) for the management of tobacco whitefly, B. tabaci, in tomato plants under poly-house condition. Contrary to present findings, they recorded the highest percent reduction on $B$. tabaci in Bio Magic (92.67\%), closely followed by Racer (91.90\%), Pacer (91.50\%), and Mealikil (90.84\%) after 3rd spray. Mealikil being less efficacious than other biopesticides can be attributed to low concentration evaluated $(2 \mathrm{~g} / \mathrm{l})$ by Sharma et al. (2015), which is in line to present observations. Abdel-Rahim and Lamya Ahmed (2017) studied efficacy of EPF, $M$. anisopliae, B. bassiana, and $V$. lecanii at 3 concentrations $\left(1 \times 10^{7}, 1 \times 10^{8}\right.$, and $1 \times 10^{9}$ spores $\mathrm{ml}^{-1}$ ) against B. tabaci in field conditions, respectively. The 3rd concentration $\left(1 \times 10^{9}\right.$ spores $\left.\mathrm{ml}^{-1}\right)$ of $V$. lecanii, $B$. bassiana, and $M$. anisopliae was the highly toxic to the adults of $B$. tabaci in tomato after 3rd application compared to the other 2 concentrations. Further, the findings of Singh and Joshi (2020) are also supportive to present investigations as they also observed the efficacy of different EPF formulations, B. bassiana, L. lecanii and $M$. anisopliae for the management of the whitefly on capsicum under protected conditions.

Significantly high yields were obtained by the use of Neem Baan (1\%) (32.5\% higher than control) that it was statistically at par with the chemical treatment. Even the 
least effective EPF, M. anisopliae gave 16.96\% higher yield than the control. The additional intangible benefit of getting nutritionally better and residue free produce cannot be overlooked.

\section{Conclusion}

Neem Baan formulations proved better results than all the fungal formulations of B. bassiana, L. lecanii, and $M$. anisopliae in reducing the populations of B. tabaci (eggs, nymphs, and adults, respectively). The efficacy of Neem Baan $1 \%$ was equivalent to the chemical insecticide (Malathion 50 EC) recommended for control of whitefly in vegetable crops. These results indicate that these biorationals can be successfully included in the integrated pest management programs designed for controlling the $B$. tabaci population on parthenocarpic cucumber under protected environment and produce organic chemical-free cucumber crop.

\section{Abbreviations}

EPF: Entomopathogenic fungi; RBD: Randomized block design; EC: Emulsifiable concentrate; N: Insect population; T: Treated; Co: Control; ANOVA: Analysis of variance; DMRT: Duncan multiple range test; CFU: Colony forming unit; DAT: Days after transplanting; PROC: Percent reduction over control; DBS: Day before spraying; et al.: Et alia (co-workers); i.e.: Id est (that is); No.: Number; NS: Non-significance; sp.: Species; SE: Standard error; viz:: Namely; LC: Lethal concentration

\section{Acknowledgements}

Authors are thankful to Head, Department of Entomology, for providing facility to conduct present experiment and special thanks to Dr. R.K Dhall, Senior Olericulturist, Department of Vegetable Science, Punjab Agricultural University, Ludhiana, for his valuable suggestions during present study.

\section{Authors' contributions}

DSG carried out the experiments, reared B. tabaci, collected the data, analyzed the data, and wrote the manuscript. KSS designed and supervised the experiments, provided technical guidance, and critically revised the manuscript for intellectual content. Both authors read and approved the final manuscript.

\section{Funding}

Not applicable.

\section{Availability of data and materials}

All data and materials are mentioned in the manuscript.

Ethics approval and consent to participate

Not applicable.

\section{Consent for publication}

Not applicable.

\section{Competing interests}

The authors declare that they have no competing interests.

\section{Author details}

'Department of Entomology, Punjab Agricultural University, Ludhiana 141004, India. '2Department of Forestry and Natural Resources, Punjab Agricultural University, Ludhiana 141004, India.
Received: 21 August 2020 Accepted: 8 January 2021

Published online: 18 January 2021

\section{References}

Abdel-Rahim MA, Lamya Ahmed AK (2017) Virulence of three entomopathogenic fungi against whitefly, Bemisia tabaci (Gennadius) (Hemiptera: Aleyrodidae) in tomato crop. J Entomol 14(4):155-159

Akmal M, Freed S, Malik MN, Gul HT (2013) Efficacy of Beauveria bassiana (Deuteromycotina: Hypomycetes) against different aphid species under laboratory conditions. Pakistan J Zool 45:71-78

Anonymous (2018) Package of practices for cultivation of vegetables (in English) 2018-2019. Directorate of Extension Education, Punjab Agricultural University, Ludhiana, India, pp 1-102

Cuthbertson AGS, Walters KFA (2005) Pathogenicity of the entomopathogenic fungus, Lecanicillium muscarium, against the sweet potato whitefly Bemisia tabaci under laboratory and glasshouse conditions. Mycopathologia 160:315319

Daniel C, Wyss E (2010) Field applications of Beauveria bassiana to control the European cherry fruit fly Rhagoletis cerasi. J appl Ent 134:675-681

Faria M, Wraight SP (2001) Biological control of Bemisia tabaci with fungi. Crop Prot 20:767-778

Gindin G, Geschtovt NU, Raccah B, Barash I (2000) Pathogenicity of Verticillium lecanii to different developmental stages of the silver leaf whitefly, Bemisia argentifolii. Phytoparasitica 28:229-239

GISD (2005) Global invasive species database (GISD) Bemisia tabaci. http://www. issg.org/database/species/ecology.

Henderson CF, Tilton EW (1955) Tests with acaricides against the brow wheat mite. J Econ Entomol 48:157-161

Jat MC, Jeyakumar P (2006) Bioefficacy of botanicals and bioagents on sucking pests of cotton. Ann Plant Prot Sci 14:8-10

Kashyap $L$ (2013) Efficacy and persistence of biorational pesticides against insect and mite pests of tomato under protected environment. CSK Himachal Pradesh Krishi Vishvavidyalaya, Palampur Ph.D. Dissertation

Li SJ, Xue X, Ahmed MZ, Ren SX, Du YZ, Wu JH, Qiu BL (2011) Host plants and natural enemies of Bemisia tabaci (Hemiptera: Aleyrodidae) in China. J Insect Sci 18:101-120

Liu TX, Stansly PA (2000) Insecticidal activity of surfactants and oils against silver leaf whitefly, (Bemisia argetifolii) nymphs (Homoptera: Aleyrodidae) on collards and tomato. Pest Manag Sci 56:861-866

Norhelina L, Sajap AS, Mansour SA, Idris AB (2013) Infectivity of five Metarhizium anisopliae (Deuteromycota: Hyphomycetales) strains on whitefly, Bemisia tabaci (Homoptera: Aleyrodidae) infesting brinjal, Solanum melongena (Solanaceae). Acad J Ent 6:127-132

Oliveira MRV, Henneberry TJ, Anderson PK (2001) History, current status and collaborative research projects for Bemisia tabaci. Crop Prot 20:709-723

Pappas ML, Migkou F, Broufas GD (2013) Incidence of resistance to neonicotinoid insecticides in greenhouse populations of the whitefly, Trialeurodes vaporariorum (Hemiptera: Aleyrodidae) from Greece. Appl Entomol Zool 48: $373-378$

Park H, Kim K (2010) Selection of Lecanicillium strains with high virulence against developmental stages of Bemisia tabaci. Mycobiology 38:210-214

Phadke AD, Phadke B (2000) Evaluation of verti-guard along with conventional and non-conventional insecticides and repellents for control of brinjal whitefly, Bemisia tabaci. Pestology 24:28-31

Pilkington LJ, Messelink G, van Lenteren JC, Mottee KL (2010) Protected biological control: biological pest management in the greenhouse industry. Biol Control 52:216-220

Poprawski TJ, Greenberg SM, Ciomperlik MA (2000) Effect of host plant on Beauveria bassiana and Paecilomyces fumosoroseus-induced mortality of Trialeurodes vaporariorum (Homoptera: Aleyrodidae). Environ Entomol 29: 1048-1053

Prijovic M, Drobnjakovic T, Marcic D, Peric P, Petronijevic S, Stamenkovic S (2012) Efficacy of insecticides of natural origin in whitefly (Trialeurodes vaporariorum) control in tomato. Acta Hortic 960:359-364

Quesada-Moraga E, Maranhao EAA, ValverdeGarcía P, Santiago-Álvavez C (2006) Selection of Beauveria bassiana isolates for the control of whiteflies Bemisia tabaci and Trialeurodes vaporarioum on the basis of their virulence, thermal requirements and toxicogenic activity. Bio Control 36:274-287

Saito T, Sugiyama (2005) Pathogenicity of three Japanese strains of entomopathogenic fungi against the silver leaf whitefly, Bemisia argentifolii. Appl Entomol Zool 40(1):169-172 
Scorsetti AC, Humber RA, Gregorio CD, Lopezlastra CC (2008) New records of entomopathogenic fungi infecting Bemisia tabaci and Trialeurodes vaporariorum, pests of horticultural crops, in Argentina. Bio Control 53:787796

Sharma M, Budha PB, Pradhan SB (2015) Efficacy test of bio-pesticides against tobacco whitefly, Bemisia tabaci (Gennadius, 1889) on tomato plants in Nepal. J Insect Sci Tech 20:11-17

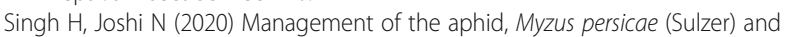
the whitefly, Bemisia tabaci (Gennadius), using biorational on capsicum under protected cultivation in India. Egypt J Biol Pest Co 30:67

Sood AK, Singh V, Mehta PK (2018) Current status and management strategies of insect-pests of vegetables crops under protected cultivation in Himachal Pradesh. In: Kumar S, Patel NB, Saravaiya SN, Patel BN (eds) Proceeding technologies and sustainability of protected cultivation for hi-valued vegetable crops. Navsari Agricultural University, Navsari, Gujarat, India, pp 339-354

Sood S, Sood AK, Verma KS (2006) Determination of baseline toxicity of some insecticides to greenhouse whitefly, Trialeurodes vaporariorum (Westwood) population from North-Western Indian Himalayas. Pest Manag Hort Ecosyst $12: 67-70$

SPSS (2015) IBM SPSS Statistics for Windows (Version 23.0). IBM Corp, Armonk Chicago, IL

Torrado-Leon E, Montoya-Lerma J, Valencia-Pizo E (2006) Sub lethal effects of Beauveria bassiana (Balsamo) Vuillemin (Deuteromycotina: Hyphomycetes) on the whitefly Bemisia tabaci Gennadius (Hemiptera: Aleyrodidae) under laboratory conditions. Mycopathologia 162:411-419

Van Lenteren JC (2000) A greenhouse without pesticides: fact or fantasy. Crop Prot 19:375-384

van Regenmortel MHV, Fauquet CM, Bishop DHL, Carstens EB, Estes MK, Lemon SM, Maniloff J, Mayo MA, McGeoch DJ, Pringle CR, Wickner RB (2000) Virus Taxonomy, Seventh Report of the International Committee on Taxonomy of Viruses. Academic, San Diego, p 1167

Zafar J, Freed S, Khan BA, Faroog M (2016) Effectiveness of Beauveria bassiana against cotton whitefly, Bemisia tabaci (Gennadius) (Aleyrodidae: Homoptera) on different host plants. Pakistan J Zool 48:91-99

\section{Publisher's Note}

Springer Nature remains neutral with regard to jurisdictional claims in published maps and institutional affiliations.

\section{Submit your manuscript to a SpringerOpen ${ }^{\circ}$ journal and benefit from:}

- Convenient online submission

- Rigorous peer review

- Open access: articles freely available online

High visibility within the field

- Retaining the copyright to your article

Submit your next manuscript at $\boldsymbol{\nabla}$ springeropen.com 